\title{
Organizational Factors Affecting Employee Performance: The Case of Selected Public Service Organizations in Dire Dawa Administration, Ethiopia
}

\author{
BINIYAM KEBEDE DESTA \\ Lecturer of Management, College of Business (Department Head of MBA) \\ Addis Ababa Medical and Business College, PO Box: 3111, Dire Dawa, Ethiopia \\ ELIAS ALEMAYEHU WAKENE \\ Lecturer of Industrial Engineering in Dire Dawa University \\ (MSC in Industrial Engineering) Dire Dawa, Ethiopia
}

\begin{abstract}
This study aims to analyze the determinants for employee performance in the Public Service Organizations, in Dire Dawa Administration, Ethiopia. Based on the literature discussed, the four factors considered as the important elements influence the employees' performance that need to be investigated. The research question lies in each of organizational factors has a significant and positive effect on employees performance. Using the quantitative method, the population of this study was 205 respondents but 181 returned the survey questions, indicating a response rate of 88 per cent. Stratified sampling technique was used to select Core Staff and Support Staff. The primary data gathered in the form of questionnaires with a Likert typed-scale were then analyzed using frequencies, percentages and inferential statistics describes the data with making inference or conclusion and summarizing sources of numerical data in to meaningful form. In this study Chi-square goodness of fit test, factor analysis, stepwise multiple linear regression model and Pearson correlation analysis were used to establish and explain the relationship between the dependent and the independent variables. In stepwise regression, to explain that it is a systematic procedure where the most significant variable(s) and least significant variable(s) are added or removed respectively. Stepwise regression was performed in sequential stages namely, regression model summary, ANOVA, and regression coefficients. The findings reveal that the value of the determination coefficient test is 89.6 percent, indicating that the employees' performance is explained by organizationalstructure,communication, Leadership/management system and culture factors, while the remaining 10.4 percent are linked with other factorsand there was a strong correlation between organization structure,communication, Leadership/management system and employees performance at $(\mathrm{r}=.777, .797$, and $.757, \mathrm{p}<0.01$ respectively). Accordingly, organization culture has a moderate positive correlation coefficient of $(r=.506, p<0.01)$, which implies that it has positive relation with employees performance. Therefore, all the independent variables have a significant positive correlation with dependent variables. The study recommends that the PSO management should build and improve on teamwork and develop the current management systems to maintain the organization culture; create opportunities for employees to interact with the managers of the PSO in order to improve on the communication; and encourage employee innovation, increase on their salaries, organizational loyalty programs and reward longserving employees.
\end{abstract}

Keywords: Structure,communication, management system, culture, employee performance and Dire Dawa Administration Public Service Organizations.

DOI: $10.7176 /$ PPAR/9-10-01

Publication date:October $31^{\text {st }} 2019$

\section{Introduction}

1.1. Background of the Study

The beginning of modern civil service in Ethiopia dates back to 1907 when Emperor Menelik II initiated the formation of few ministers. Later Emperor Haileselassie I introduced various reform measures in modernizing public administration and in the appointment of salaried and educated personnel in the civil service based on the criteria of loyalty to the monarch and their family status rather than merit. The derg(1974-1991) continued the centralization policy of the Emperor and seriously affected the development and professionalism of the civil service. Generally, the civil service during the three regimes was not a neutral policy implementer, responsive to the peoples' interests, impartial, transparent, and accountable; among others, the civil service, as an institution was not professional and loyal to the public. After the downfall of the Derg regime (since 1991), the current Government of the Federal Democratic Republic of Ethiopia has been taking some encouraging initiatives and reforms in economic, political and socio-cultural aspects against unprofessional, undemocratic and backward systems of the civil service in the past regimes (Tilaye, 2007). The Public Service is faced with a workplace plagued with a multitude of factors that interfere on the effective delivery of crucial services, which it provides. In 
order for a public sector organization or government institutions to deliver on its mandate of service delivery to public, so that organizational factors in the public service organization plays an important role and as a backbone to fulfill the ever changing needs of employees performance. Hence, performance of employees' is viewed as the implementation of an action or one's ability. Good performance is also related with achieving the quality, quantity, cooperation, dependability and creativity.

Employee performance is considered as the measures of the quality of human capital which was held by the organization and is a key factor in Ethiopia Public Service Institutions. According to Churchill, Ford and Walker, (1987) the determinants of performance are personal, organizational, environmental, motivation, skill level, aptitudes and role perceptions. Performance management is a continuous process of identifying, measuring, and developing the performance of individuals and teams and aligning performance with the strategic goals of the organization (Smither\& London 2009). Moreover, they promote public service values such as integrity, economy, efficiency, effectiveness, transparency, accountability, responsiveness, representativeness, political neutrality, respect, fairness, honesty, merit, equity, impartiality and professionalism (Huff, 2011) as cited in Edgar, (2014). The main objective of human resources management is to utilize the human resources in a most optimal manner so that targets can be achieved very effectively and efficiently. For this purpose managing performance of employees as a whole is very important.

Performance management takes care of this function. Performance management maintains, develop and motivate the people at work to give better results. In the present competitive situation the organization that gives better results can survive, stabilize, grow and excel in the performance. Ferris et al (1998) assert that effective human resource system is based on supporting values that create a positive impact on employees' attitudes and behaviors which in turn influence their performance been claimed that employee performance can be improved by developing and creating certain kinds of organizational cultures (Sackman\&Bertelsman, 2006). It helps a lot in achieving the objectives of HRM. Performance management includes activities to ensure that goals are consistently being met in an effective and efficient manner. Performance of an organization is the outcome of activities of individuals and units of the organization. Except for the external influences on individual behavior and personal traits, organizations can either influence or control all factors affecting the performance of individuals and units through formal and informal means. Some of the formal means of controlling units' activities are structure, operating manuals, standard operating procedures, charters, and budgets. Greater influence on individuals can be exercised informally through communication, work culture, management style (Ramanadh, 2006).

Foot and Hook, (2008) asserted that employees need to be given the ability to contribute to the performance of the firm together with the means and incentive to do so. They further argued that the management should work in partnership with its employees for continuous and increased production with involvement and partnership practices, and also asserted that organizations should attempt to maximize their employee's contribution to the achievement of organizational goals so that employees have the ability to add value through high-performance working while at the same time directly benefiting employees themselves. Gruber (2014) asserted that in order for public institutions to provide services of good quality to the customers of public institutions, the employees should be knowledgeable, well-organized, encouraging, helpful, caring to customers' needs, approachable, experienced, friendly and should have good communication skills.

Rendering services of good quality will help improve the productivity of public institutions. Performance management is about establishing a culture in which individuals and groups take responsibility for the continuous improvement of business processes and of their own skills, behavior and contributions. It is about sharing expectations. Furnham, (2004) states that managers can clarify what they expect individual and teams to do; likewise, individuals and teams can communicate their expectations of how they should be managed and what they need to do their jobs. It follows that performance management is about interrelationships and about improving the quality of relationships, between managers and individuals, between managers and teams, between members of teams and so on, and is therefore a joint process.

Besides, the little number of studies conducted on the performance of employees in public service organizations/institutions is affected by organizational factors has not been enough to see its practices' prevailing facts. Hence, this study was conducted to investigate the relationship between organizational factors and employees' performance is important to share experience and advocate its basic essence for the rest of public service organizations of the country.

\subsection{Statement of the Problem}

Globally, there seems to be a performance crisis in public service, while there is need to produce more for less. This problem strikes through poor, developing and developed countries and has raised the appetite for efficiency and the need for evaluation mechanisms to help assess the performance of government institutions or programs that are quite inadequate in stakeholder expectations (Nabukeera, Ali \& Raja, 2014). In Ethiopian context, the government has shown commitment to improve public service leadership by launching different initiatives under the scope of Civil Service Reform Programs (CSRP). Public service leaders at different level advocate 
transformational agenda to achieve Growth and Transformational Plan (GTP) goals. However, public service organizations' performance highlighted a number of implementation deficiencies in terms of effectiveness, efficiency and a leadership practice has not been up to expectations (Zerihun\&Tesfaye, 2014). Organizations have set clear visions and missions who they intend to achieve (Mbithe, 2012). He further asserts that managing employee performance is one of the key drivers for organizational success in the present context of organizations trying to adopt a resource centered view of the organization hence management of different organizations have different factors that influence employee performance in their organizations.

Stup (2003) as cited in Naharuddin and Sadegi, (2013), explains that the success of the employees' performance is based on certain factors such as physical work environment, equipment, meaningful work, performance expectation, feedback on performance, reward for good or bad system, standard operating procedures, knowledge, skills and attitude. They also emphasized that a number of factors may be affecting the employees' performance where by each employee may have a different impact from different things at the workplace as well as their attitude and behavior can play a vital role in their performance. Consequently, performance objectives are often ill defined. Several issues are reports to be affecting performance of staff. A few studies done by different scholars have identified manager's attitude, organizational culture, personal problems, job content, financial rewards, communication, norms and standards used at work as some of the factors affecting employee performance (Saeed et al, 2013, as cited in Naharuddin\&Sadegi, 2013).

The performance management system may fail because of inadequacies of its critical components such as performance appraisal, performance planning, feedback and coaching, and performance reviews (Glassman, et.al 2011) as cited in Nabukeera, et.al (2014). As argued by Kiragu and Mutahaba (2006), the implementation of the performance management system in African public services often fails because of lack of an integrated approach. Moreover, there is often lack of alignment of the performance management system with human resource management systems and other institutional systems/ organizational factors. Subsequent reasons of Adebabay (2011), as cited in Bersisa, et al, (2016) performance management system Ethiopian civil service organizations top leaders in the civil service were not developed and managed adequately, systematically and rationally, low level of leadership competencies and poor design of work structures and very weak working cultures.

According to Zerihun and Tesfaye, (2014) study was to investigate the extent of leadership effectiveness in Ethiopian public service organizations at federal and regional levels. The key findings revealed that the changes in Ethiopia enabled to create demanding society for improved services. However, leadership effectiveness is not at its required level to transform public service organizations in terms of striving for performance in order to be globally competitive and manage changes. Lack of motivation and communication of the vision and the commitment to reform is often criticized as inadequate, since many institutions are lacking leadership capabilities, and the accountability relationship between government and public service providers has not been clarified. There is high degree of variation among managers of different levels in the areas of organizational performance. Public organizations in Kenya face a crisis of performance associated with poor leadership (Mutunga, 2011). Therefore, leadership style has a significant contribution on how the subordinates perform in their arena of work. Recent study carried out in Kenya among Companies of the Year Award, Lumbasi et al. (2015), concluded that leadership style had a significant impact on employee performance. Olowu (2009) identified four key challenges of performance management in Africa as: lack of a common vision or lack of communication of a leadership vision; non-alignment of people strategies to organizational strategy; managers focusing on short-term issues rather than long-term issues; and failure of public sector organizations to link budgets to strategy.

According to MacDonald (2003) effective leadership leads to efficiency, specialization,effective feedback and good organizational relations. The cohesion of both leadership andperformance should be evident through style and approach by managers in the attempt to causeefficiency which requires specific leadership approaches to unique performance challenges. It isargued that effective leadership has a positive sway on the performance of an institution/organization. Performance was conceptualized by attributes of efficiency, quality work, improved productivity as well as timeliness in task completion.In response to the prevailing organizational performance gaps, performance management allows managers and supervisors to use as tools of organizational factors to enable staff to do their best in their respective job roles and assignments.

Research of Mohammed and Abukar (2013), Femi (2014), and Ahmad et al, (2014) has been conducted on the combined effect of organizational culture, organizational communication and organizational commitment in influencing employees towards the attainment of the organizational performance goals and objectives which are essential to management. This is despite the three factors being recognized as central drivers of employee performance. A few studies done by different scholars have identified managers' attitude, organizational culture, personal problems, job content, financial rewards, communication, norms and standards used at work as some of the factors affecting employee performance (Saeed et al, 2013; Zahargier and Balasundaram, 2011; Nassazi, 2013; and Amari, 2014).

Iskandar et al., (2014) study of factors influencing employees' performance using such analysis of employees' performance, the three influencing factors such as job stress, motivation and communication enable them to be 
compared with other studies in the conventional workplace systems. This study concludes that the variables of job stress, motivation and communication do simultaneously affect the employees' performance at the two Islamic banks. It also states that the partial test shows that both job stress and motivation variables respectively do not partially affect the employees' performance, while the communication variable has partial effect on employees' performance. Their study were not analyzed other factors that may influence employees' performance that can potentially occur. As a matter of fact that most administrative in government organizations/institutions including state government will face with a crucial question of what factors influence employee performance and inadequate empirical information that might guide their efforts in enhancing overall job performance among employees.

Building on this study, the researcher wish to bridge the gaps identified from literatures by putting more emphasis and focus on the critical organizational factors play towards the improvement of employees' performance at public service organizations. There is limited research on how the performance of employees in public service organizations/institutions is affected by organizational factors. Therefore, the researcher also analyzed among other variables of the organizational factors such as (organizational culture, organizational communication, organizational structure and organizational management/leadership system) influence on employees' performance; no study has been conducted on the combined effect of organizational factors at Dire Dawa Administration Public Service Organizations.

\subsection{Research Questions}

This research proposes to answer the following key questions:

1. To what extent does the organization structure influence employees' performance in the public service organization?

2. How organizational culture influenced performance of employees working at public service organization?

3. To what extent does the organizational communication influence performance of employees working at public service organization?

4. What influence do different types of management/leadership system have on the employees' performance in the public service organization?

\subsection{Objectives of the Study}

\subsubsection{General objective}

The main objective of this study is to analyzeorganizational factors affected on employees' performance in Dire Dawa Administration a case of selected public service organizations.

\subsubsection{Specific Objectives}

The objectives of this study were to:

1. Analysis of organization structure influence the employees performance of public service organization

2. Examine how organizational culture influences employees performance at public service organization?

3. Find out how organizational communication influences performance of employees at public service organization

4. Examine how the management/leadership system influences the implementation of performance management system at public service organization.

\subsection{Hypotheses of the study}

H0: There is no significant relationship between Organizational factors and employees performance.

H1: There is significant relationship between Organizational factors and employees performance.

\section{REVIEW OF RELATED LITERATURE}

\subsection{The concepts of employee performance and organizational factors}

According to Armstrong and Baron (2004), Performance Management (PM) is defined as; a strategic and integrated approach to delivering sustained success to organizations by improving the performance of the people who work in them and by developing the capabilities of teams and individual contributors. Further elaborated that $\mathrm{PM}$ is as strategic in the sense that it is concerned with the broader issues facing the business organization concerned with performance improvement in order to achieve organizational, team and individual effectiveness, and concerned with development, which is perhaps the most important function of performance management. Organizations, as stated by Lawson (1995, as cited in Armstrong and Baron, 2004), have to get the right things done successfully. Performance is not only about what is achieved but also about how it is achieved.

The employees' performance is affected by multiple factors. Sometime one or more factors play there role to increase or decrease the labour productivity. The factors those affect the performance or productivity are the same. Because when the productivity of individual is increased automatically his/her performance is also increased. We should not get confused with the factors affecting productivity or performance. The management experts have classified these factors: (a) Physical, organizational, location, and technological. (b) Cultural and behavioral. (c) 
Global influences, innovativeness, strategic alliances, liberalized policies etc. (d) Managerial and organizational structure. (e) HR policies, individual rewards \& recognition, incentives and payment systems, and the effectiveness of personnel managers and others in recruiting, training, communicating, and motivating employees. (f) Working conditions, working hours, nature of job and location of work. (g) Job security, welfare and social security. (h) Salary packages. (i) Liberty at work to perform. (j) Quality of leadership. (k) Motivation of employees. (1) Career development opportunities. (m) Organizational culture. (n) Management approach. Sinha (2001) as cited in (Naharuddin and Sadegi, 2013) emphasized that employees' performance depends on the willingness and openness of employees on doing their job. Further, he stated that by having this willingness and openness of the employees in doing their job, it could increase the employee's productivity which also leads to the performance. On the other hand, regardless of the employee skills and experience, necessary resources to perform have to be made available for employees, tools and materials.Organizations have set clear visions and missions who they intend to achieve (Mbithe, 2012). He further asserts that managing employee performance is one of the key drivers for organizational success in the present context of organizations trying to adopt a resource centered view of the organization hence management of different organizations have different factors that influence employee performance in their organizations.

\subsection{The effect of organizational culture on employees' performance}

The culture of the organization should be developed to support continuous improvement in employee's performance so that employees are able to identify with the values, norms and artifacts of the organization, hence the need for organizational culture (Ojo, 2009). It is through this process that employees learn about the organizational culture and decide whether they can cope with it or not, meaning that an organization is a learning environment. It makes employees understand that organizational culture makes employees perform better, hence understanding more of performance as the extent to which an individual is carrying out an assignment or task (Cascio, 2006). For two decades, many scholars have studied the nature and scope of organizational culture and those who have worked on the employee's participation in the organizational success agree that there is a significant influence of culture and organizational success. Aftab, Rana and Sarwar (2012) considered Denison's four dimensions of organizational culture and role based performance in identifying the relationship. The link between the four components was shared in order to sustain the competitive corporate world. The result of the research concluded that culture of an organization has direct impact on the performance of employees. According to Scholz (1987), as cited by Tameemi et al (2014), claimed that organizational culture is linked to performance and is also founded on the perceived role that culture can play in generating the organization's competitive advantage. However, Ogbonna (1992) argues that some widely shared and strongly held values enable management to forecast employee reactions to certain strategic options, hence minimizing the scope for undesired consequences.

In addition, Krefting and Frost (1985), also cited by Tameemi et al (2014), suggest that the way organizational culture creates competitive advantage is by defining the boundaries of the organization in a manner that facilitates individual interaction by limiting the scope of information processing to appropriate levels. The different values and beliefs based upon employee performance helps in organization association. They argue that the organization's culture helps in internalizing joint relationship that leads to manage effective organization processes. They also confirm that the productivity and culture of an organization helps in improving employee performance.

Awad and Saad, (2013), their study, they observe that strong impact of strong organization culture leads to increased productivity. According to Shazadet.al (2013) asserts that a strong culture within the organization leads to raise the employee's commitment towards achieving the goals of the organization on a common path because it is very helpful to increase the performance of the employees. They also contend that personal beliefs are different from the organizational values when an employee is entering in the organization, whereas in a strong culture, employees are on the common path towards achieving organizational goals, which provide the opportunity to the employees to grow and perform well in the organization. Earlier studies indicated a relationship between organizational culture and employee's performance. Magee (2002), as cited in Agwu (2014), argued that organizational culture is inherently connected to organizational practices which in turn influence employees' performance but Hellriegel and Slocum (2009) contend that organizational culture can enhance employees' performance if what sustains it can be understood. Thus, the culture of an organization acquaints employees with the organization's history as well as current methods of operation that guide employees on expected and acceptable future organizational behaviors and norms.

\subsection{The effect of organizational communication on employees' performance}

Communication considered as an important ingredient in the work setting of the organization. Organizational communication is a way to develop a strong culture within the organization to achieve the set goals and objectives. In this regard, Scholfelder (1998), cited in Roos (2008), defines organizational communication as an approach in which everyone should participate to create an effective culture within the organization. This leads to sharing of 
knowledge, opinions and ideas which results into innovation, effective decision-making and also increase in the productivity of an organization. He also found in his study that managers spend 70-80 per cent of their daily time in communicating with others and if both the employees and managers communication skills increase by 10 per cent, this would lead to 7 per cent increase in productivity.

According to Hellweg and Phillips (1982), cited in Mahdieh (2015), employee performance increases when there is communication within the organization and, besides other things, communication within the organization helps the employees to perform their tasks well, to have information about the duties they have to perform, and about the goals of the organization. They argue that existence of communication within the organization leads to effective decision-making. In their study, Smidts, Pruyn and Riel (2001) define communication as a transaction. They argue that employees who are well informed about organizational activities as goals and objectives, new developments and achievements can enable the organization's members to develop such characteristics which differentiates it from other organizations hence improving on the performance of employees. They, also found that communication climate is an important variable in the relationship between organizational communication and employee performance where there is lack of communication, decision-making becomes difficult. Previous researches show that there is a strong bond between communication and other organizational functions. More specifically, a study by Monge, Cozzens and Contractor (1992) shows that communication variables like information sharing and communication between group members lead to innovation in the organization. They found that communication variables have a strong effect on the organizational outcome, which strengthens their arguments that the participative environment within the organization increases its productivity and improves its performance and outcomes.

Effective communication in the work setting of any organization promotes trust in the employees especially if they are getting involved in decision-making; or when they are empowered, this automatically increases their confidence level and definitely has a positive effect on the performance of the employees. In the previous studies conducted on organizational communication, some scholars suggest a visible relation between trust and communication. In relation to this, Yamaguchi (2009) proposes that there exists a strong relation between organizational communication and trust. He predicts that bad news, such as failure of proposals or low performance, may result in developing a bad perception of employees about their bosses, whereas good communication between superiors and employees leads to good results in the organization. Furthermore, he explains that good communication can change the attitude of employees for the desired results. Therefore, communication decreases the uncertainty while effective communication enhances the trust and increases job satisfaction, employee's commitment and their loyalty towards work. He also found that effective communication breaks the wall of misunderstanding and conflicts in an organization.

\subsection{The effect of organizational structure on employees' performance}

An organization structure can be defined to be the lines of authority, reporting and coordination, as well as real and perceived career paths and decision-making authority (Hrebiniak, 2005). There are different types of organization structures which can be essential in performance management systems implementation if proper matching of structure with strategy is done (Mills, et al., 2013). The key components of organizational structure to be addressed in this section include work specialization, and rules and regulations.

The structure of an organization has important implications for performance. An organization structure is mainly a hierarchical concept of subordination of entities that collaborate and contribute to serve one common aim. The structure of an organization will determine the modes in which it operates and performs. Organization structure allows the expressed allocation of responsibilities for different functions and processes to different entities such as branch, department, workgroup and individuals. Performance management requires that individuals in the organization know their role and responsibilities (Markus, 2014). The same tasks and responsibilities ought to be considered while evaluating the performance of individual employees (ibid). The components of organization structure are hierarchy, Work specialization, rule and regulations.

Oyewobi et al. (2013), organizational structure includes the nature of layers of hierarchy, centralization of authority, and horizontal integration. It is a multi-dimensional construct in which concerns: work division especially roles or responsibility including specialization, differentiation or departmentalization, centralization or decentralization, complexity; and communication or coordination mechanisms including standardization, formalization and flexibility. The main feature of new organizational structures is the flexibility and the ability to acclimatize to the changing environment. (Ibid) study on impact of organizational structure and strategies on construction organizations performance, found that organization structure has direct impact on performance management systems of employees performance.

\subsection{The effect of management/leadership system on employees' performance}

Kyarimpa (2009) advises that leadership is a key factor to the successful implementation of a performance management system. This is especially in developing nations where majority of the organizations lack effective 
leadership (Harrington, 2006). Effectively, in such organizations emphasis is placed on shorter-term frames, strong focus on command, control and predictability, with little emphasis being placed on employee empowerment and motivation.

Harrison (2013) indicates that senior executive management has a significant impact on the strategies and performance of their organizations. This is also the case for excellent leadership, which also has an enormous positive influence. The influence of leadership can take both positive and negative dimensions. It follows therefore that poor leadership can have a powerful negative influence and create dissonance amongst employees (Worley \&Doolen, 2006). In order for performance management systems to be successful, there need to be a collaborative process between supervisors and employees. Human Resource tasks such as performance management affect and include employees as well as supervisors. This inclusion will influence the quality of the relationship and improve on perceptions as pointed out by (Manville \&Greatbanks, 2013).

McGrath and MacMillan (2010) reported that there is a significant relationship between leadership styles and performance management systems. Effective leadership style is seen as a potent source of management development and sustained competitive advantage, leadership style helps organization to achieve their current objectives more efficiently by linking job performance to valued rewards and by ensuring that employees have the resources needed to get the job done. Another study at Big Company of USA found that those leaders who follow the bureaucratic model in the company, results in restricted interaction patterns where the social interaction between employees is very low which indeed leads to low sharing (Kleinbaum, Stuart \&Tushman, 2008). They go ahead and argue that social interaction is the core of any business and there should be a good interaction between the leaders and the employees. Sun (2012) compares leadership style with the leadership performance management in schools and enterprises, and found that leadership style had a significantly positive correlation with the organizational performance management in both schools and enterprises. Broadly speaking, leadership performance is identical with organizational performance management. FuJin et al. (2010) opine that when executives use their leadership style to demonstrate concern, care and respect for employees, it would increase interest of employees in their work and enable them to put up better performance, thereby affecting their job satisfaction positively. A strong sense of purpose is normally the discretion of true leadership as such it plays an important role in harnessing the creative energies of all the people in the business Schultz et al. (2013). An exceptional leadership is a key ingredient to making strategic change effective and lasting (Daft, 2010).

\section{RESEARCH METHODOLOGY}

\subsection{Research Design}

This research problem was studied through the use of a descriptive and explanatory research design. A descriptive study is concerned with finding out the what, where and how of a phenomenon. According to Mugenda and Mugenda (2003), descriptive design is a process of collecting data so as to answer questions regarding the current status of the subject of the study. Secondly, the study employs explanatory in that the relationship between variables is correlated with an aim of estimating the integrated influence of the factors on performance.

\subsection{Sources of Data}

To complete this study both primary and secondary data have been collected. The data used for this study are primary quantitative data from the respondents using five point Likert scale self-administering questionnaires. The secondary sources of information that the researcher used in this study included relevant literatures, Human Resources Manual, appropriate journals, magazines, articles and other similar studies conducted in the field were gathered, reviewed and used to substantiate the intended objectives to make the study fruitful.

\subsection{Research Instrument /Tools}

The researcher used one major research instruments and questionnaire close-ended questions only.

Meanwhile, whether to ask a question in an open or closed format is one of the most significant considerations for many researchers. In this research, a self-completion questionnaire with closed questions was developed. The selfcompletion questionnaire is very familiar method of business research, and the research instrument. According to Bryman and Bell, (2003) closed questions have some advantages: it is easy to process answers; it enhances the comparability of answers, and makes them easier to show the relationship between variables. It is better than open question for this research.

\subsection{Sampling Method and Sample Size Determination 3.4.1. Sampling Method}

According to Kothari (2004), if a population from which a sample is to be drawn does not constitute a homogeneous group, stratified sampling technique is generally apply in order to obtain a representative sample. Stratified random sampling method employed the study to get information from different sizes of the Public Service Organizations. This technique is preferred because it assists in minimizing bias when dealing with the 
population.

\subsubsection{Target Population}

The target population for the study Dire Dawa Administration Technical and Vocational Education Training College (DDATVETC), Health Bureau, Construction Bureau and Dire Dawa Mass Media Enterprise. The actual population selections were considered as representative of Core processor and Supportive processor.

Table 3.1 Target Population

\begin{tabular}{ll|l}
\hline Organizations & Core Staff & Support Staff \\
\hline TVETC & Academic staffs & Finance \\
Health Bureau & Health workers & HRM \\
Construction Bureau & Engineers, surveyors... & Plan and Program \\
& & \\
DDMME & Journalists & \\
\hline
\end{tabular}

\subsubsection{Sampling Size}

To determine the sample size and representative of the target population, the study was used statistical instrument formula. The following formula used for the calculation of the sample size since it is relevant to studies where a probability sampling method is used (Watson, 2001). The sample size of study computed as follows.

$$
\mathrm{n}=\left[\begin{array}{c}
\frac{p[1-p]}{N} \\
\frac{A 22}{Z}+\frac{p[1-p]}{N}
\end{array}\right]
$$

Where, $\mathrm{n}=$ sample size required $=205$

$\mathrm{N}=$ number of population $=478$

$\mathrm{P}=$ estimated variance in the population $=50 \%$

$\mathrm{A}=$ margin of error $=5 \%$

$\mathrm{Z}=$ confidence level $=1.96$ for $95 \%$ confidence

$\mathrm{R}=$ estimated response rate $=96 \%$

The proportional stratified sampling for each stratum will be determined by $\mathrm{n} / \mathrm{N}=205 / 478=0.43$ which means that $43 \%$ of each clusters as calculated in the table.

Table 3.2 proportional stratified sample

\begin{tabular}{llll}
\hline Organizations & Employee's Stratum & Population & Sample 43\% \\
\hline Construction Bureau & Core Staff & 39 & 17 \\
& SupportStaff & 24 & 10 \\
TVETC & Core Staff & 98 & 41 \\
\multirow{2}{*}{ Health Bureau } & Support Staff & 48 & 21 \\
& Core Staff & 112 & 47 \\
DDA Mass Media Agency & Support Staff & 56 & 24 \\
& Core Staff & 78 & 33 \\
\hline TOTAL & Support Staff & 23 & 9 \\
\hline
\end{tabular}

Source: Survey Result (2018)

According to Mugenda and Mugenda (2003) a sufficient number would be $10 \%$ to $50 \%$ of the total population, accordingly the researcher considered $205(43 \%)$ respondents from each strata.

\subsection{Method of Data Analysis}

After gather, all necessary information the intended tools data processing and analysis would be properly implemented. The data was then processed using Statistical Packages for Social Sciences (SPSS) Software Version 23 and analysis methods included descriptive and inferential statistical techniques. Statistics analysis entails organizing data for description and decision-making. Depending on the data type, both descriptive and inferential statistics were used to analyze it.

\subsubsection{Inferential Statistics}

It describes the data with making inference or conclusion and summarizing sources of numerical data in to meaningful form. In this study Chi-square goodness of fit test, stepwisemultiple linear regression analysis and Pearson correlation analysis were used to establish and explain the relationship between the dependent and the independent variables.

\subsubsection{Multiple Linear Regression (Stepwise Multiple Linear Regression Method)}

Multiple linear regressions require at least three independent variables, and in this study, the independent variables 
were four. The study applied stepwise regression method. Stepwise regression method entails automating the procedure for choosing predictor variables (Saunders et al., 2016). In each step, a variable is considered for addition to or subtraction from the set of explanatory variables based on some pre-specified criterion. In stepwise regression, Saunders et al., continue to explain that it is a systematic procedure where the most significant variable(s) and least significant variable(s) are added or removed respectively. Stepwise regression was performed in sequential stages namely, regression model summary, ANOVA, and regression coefficients. Regression model summary was used to provide information about the regression line's ability to account for the total variation in the dependent variable $(\mathrm{Y})$. ANOVA was used to test the differences in means. Regression coefficient was used to examine the rate of change in the dependent variable (Y), as a function of changes in the independent variables (X: $\left.x_{1}, x_{2} \ldots x_{n}\right)$ (Hair et al., 2007). ANOVA was done by examining the change in R squared and F-ratio values, and evaluating the significance given the critical p-value of 0.05. An important stage in stepwise regression is the coefficient stage. In this study, coefficient stage was to show the regression variant of the model. Besides, Beta-values, that are standardized coefficients, were used to examine the relationship between independent and dependent variables. The level of influence i.e. level of prediction by independent variables was determined by considering the size of the Beta-values.

The multivariate/multiple regression for the study was in the following form:

$\mathbf{Y}=\alpha+\beta_{1} \mathbf{X}_{1}+\beta_{2} \mathbf{X}_{2}+\beta_{3} \mathbf{X}_{3}+\beta_{4} \mathbf{X}_{4}+\varepsilon$

$\mathbf{Y}=$ Employee's performance (Dependent Variables)

$\mathbf{X}=$ Organizational Factors (Independent Variables)

$\mathbf{X}_{\mathbf{1}}$, Organizational Culture

$\mathbf{X}_{2}$, Organizational Management style

$\mathbf{X}_{3}$, Organizational Structure

$\mathbf{X}_{4}$, Organizational Communications.

$\boldsymbol{\alpha}$ is intercept of operational performance; its mechanical interpretation is the average value of employee's 1 performance when the stated independent variables are set equal to zero, $\mathbf{C}$, error term. Therefore, each independent variable is weights by the regression analysis procedure to ensure maximum prediction from the set of independent variables (Hair et al., 1998).

\section{RESULTS AND DISCUSSIONS}

\subsection{Response rate}

The survey was conducted between October 2018and May 2019. Questioners were distributed to 205 randomly chosen employees.

Table 4.1: Response rate

\begin{tabular}{lcc}
\hline Participants & Frequency & Percentage \\
\hline Responded & $\mathbf{1 8 1}$ & $\mathbf{8 8}$ \\
Non responded & $\mathbf{2 4}$ & $\mathbf{1 2}$ \\
Total & $\mathbf{2 0 5}$ & $\mathbf{1 0 0}$ \\
\hline
\end{tabular}

Source: Survey 2018

As indicated in table 4.1above, Out of 205 sample, 181 questionnaires were returned fully completed, 19 and 5 from Core processor and Supportive processor respectively total 24 questionnaires were not returned giving a response rate of $12 \%$. The overall response rate of the respondents was thus $88 \%$.

\subsection{Respondents' Profile}

Under this section, the researcher analyzed the respondent's profile, which includes gender, age, educational level, position, department and years of experience of respondents who were involved in this study. As indicated in table 4.2, from the total 181 respondents, $50.3 \%$ (90) were male respondents who took slightly small share of the total respondents and the remaining 49.7\% (90) were female respondents. This presupposes that generally, the margin between males and females were minimal. This implied that there was fairly (equal) representation of the male and female employees in Dire Dawa Administration Public Service Organizations. The SPSS results showed that, the largest proportion of the respondents fall on the age group between a range of $36-45$ years, which is $40.9 \%$ (77), followed by the second largest proportion of the respondents aged between $26-35$ years, which is $27.1 \%$ (49). The third largest proportion of the age group is between $46-55$ years, which is $22.7 \%$ (41), followed by an age group less than 25years, which is also $8.3 \%(15)$ and above 56 years is $1.1 \%(2)$. We can conclude that the majority of the respondents were aged between $26-55$ years. The data collected showed that, the largest proportion of the respondents, which is 58\% (105), of them had attained Bachelor's Degree and the second largest proportion of the respondents, which is $19.9 \%$ (36) TVET graduate and the third largest proportion of the respondents, which is $13.3 \%$ (24) holds Postgraduate Degree and above. The remaining respondents, which is $7.7 \%$ (14), have College Diploma and 1.1\% (2) High School Complete. The fact that the majority of the respondents 
were knowledgeable enough to contribute positively, means that they well understood the question from the questionnaire and the responses obtained were reliable. The collected data shows that, the highest percentage of the respondents, which is $43.1 \%$ (78), served the organization for greater than 17 years. The second largest percentage of the respondents, which is $33.1 \%$ (60), worked for 11-16 years and the third largest percent of the respondents, i.e. $14.9 \%(27)$ served the organization for $6-10$ years. The rest were $8.8 \%(16)$ with service years of less than 5 years. As illustrated in the Methodology in the previous chapter and as the data collected evidenced, a wide number of respondents were from Core Staff, which is 67\% (122), and followed by SupportStaff, which is $33 \%(59)$.

\subsection{Descriptive Statistics}

Table: 4.1. Presents the descriptive statistics of the variables, looking at the mean scores and standard deviations of the variables which do not vary much, it shows that pattern of response were quite similar with one another. However, the analysis indicated that organizational structure has the highest mean score of 4.00 with standard deviation of 0.879 compared to all other variables. This means that all the respondents agreed that in their organizations are organizational factors affected on employees' performance. For the public sector all variables of organizational factors were at least regarded as important if the (mean $>3.5$ ).

Table: 4.2. Descriptive Statistics on the Variables

\begin{tabular}{lccc}
\hline Organizational Factors & Mean & Std. Deviation & N \\
\hline Organizational Structure & 4.00 & .879 & 181 \\
Organizational Communications & 3.51 & .909 & 181 \\
Organizational Management/Leader systems' & 3.73 & 1.221 & 181 \\
Organizational Culture & 3.52 & .688 & 181 \\
Employee's performance & 3.62 & .526 & 181 \\
\hline
\end{tabular}

Source: Survey Result (2018)

\subsection{Factor Analysis Results on Organizational Factors on Employees' Performance}

Factor analysis was done on the variables to determine the adequacy of the sample used. Factor analysis refers to the statistical tool that examines the weight or the possible effect of un-observed variables. The recommended value for KMO should be close to 0.5 or more (Kaiser, 1974). Looking at the table 4.3, the KMO measure is 0.671 which lies in the acceptable range. The analysis also indicates the strength of the relationship that exists between the variable and can be used to test the null hypothesis using the Bartlett's test of sphericity.

Table 4.3: KMO and Bartlett's Test for Organizational Factors on Employees' Performance

\begin{tabular}{llr} 
Kaiser-Meyer-Olkin Measure of Sampling Adequacy. & .648 \\
Bartlett's Test of Sphericity & Approx. Chi-Square & 623.587 \\
& df & 10 \\
& Sig. & .000 \\
\hline
\end{tabular}

Source: Survey Result (2018)

\subsection{Assessing implementation level of organizational factors}

The overall, organizational factors of affected on employees' performance in Dire Dawa Administration a case of selected public service institutions is illustrated the following table.

Table: 4.4. One-Sample Test

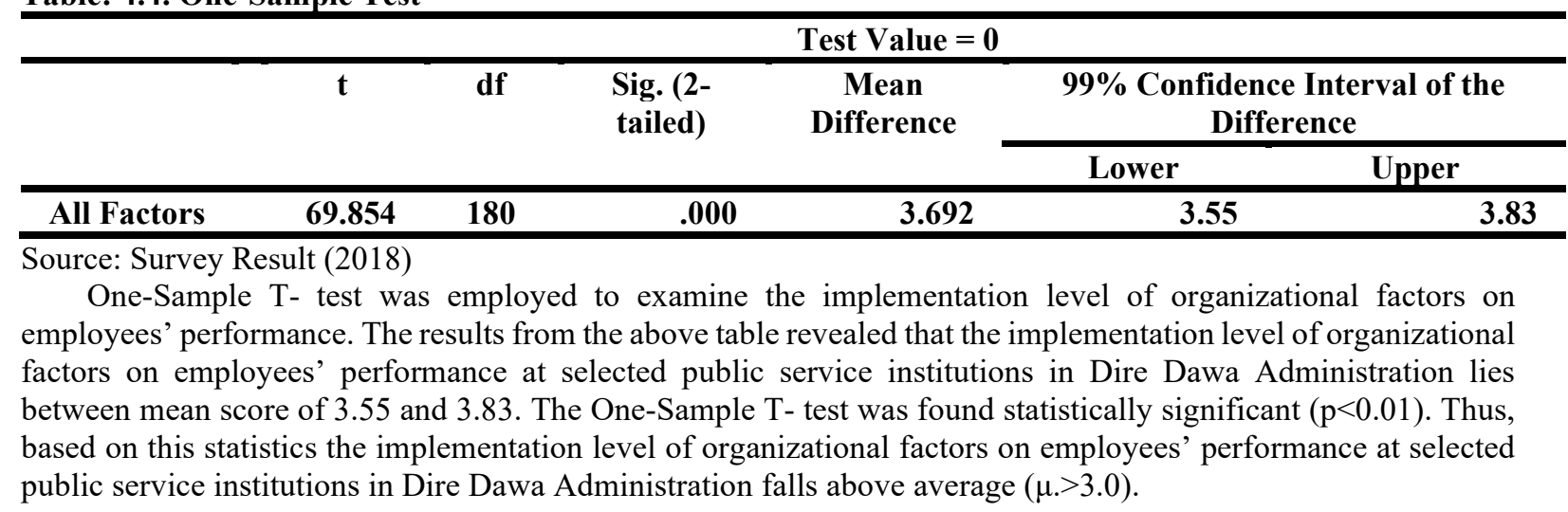

\subsection{Reliability of the Survey Instrument}

The instrument of data collection was also subjected to reliability analysis. In this research, the internal consistency 
method was adopted for estimating reliabilities. It has advantage of being a single test administration. Cronbach's alpha was used to access the internal consistency.

Table 4.5: Reliability of Statistics

\begin{tabular}{lcc}
\hline Variables & Number of Items & Cronbach's Alpha \\
\hline Organization structure & 7 & .780 \\
Organization management/leadership & 7 & .743 \\
Organizational communication & 6 & .813 \\
Organization culture & 7 & .840 \\
Overall implementation of performance & 6 & .746 \\
\hline
\end{tabular}

Source: Survey Result (2018)

Table 3.4 shows that the Cronbach's Alpha coefficient of five variables ranged from 0.743 to 0.84 (coefficients 0.7 and above). These scores were acceptable according to (Nunnally, 1967). The value equaled to 0.7 and above, then the instrument was considered satisfactory (Cronbach, 1951; and Sekaran\&Bougie, 2010).

\subsection{Correlation between Organizational Factors and Employees' Performance}

The Pearson correlation coefficient, $\boldsymbol{r}$, values range from +1 to -1 , which is coefficientrcan show either a negative or positive relationship. The findings in Table 4.6 suggested that there was a strong correlation between organization structure,communication, Leadership/management systemand employees performance at $(\mathrm{r}=.777, .797$, and $.757, \mathrm{p}<0.01$ respectively). Accordingly, organization culture has a moderate positive correlation coefficient of $(\mathrm{r}=.506, \mathrm{p}<0.01)$, which implies that it has positive relation with employees performance. Table: 4.6. Correlation Analysis between Organizational Factors and Employees' Performance

\begin{tabular}{|c|c|c|c|c|c|c|}
\hline & & $\begin{array}{l}\text { Employee'sperform } \\
\text { ance }\end{array}$ & $\begin{array}{l}\text { Structu } \\
\text { re }\end{array}$ & $\begin{array}{l}\text { Communicat } \\
\text { ion }\end{array}$ & $\begin{array}{l}\text { Managem } \\
\text { ent system }\end{array}$ & $\begin{array}{l}\text { Cultu } \\
\text { re }\end{array}$ \\
\hline \multirow{5}{*}{$\begin{array}{l}\text { Pearson } \\
\text { Correlati } \\
\text { on }\end{array}$} & $\begin{array}{l}\text { Employee's } \\
\text { performance }\end{array}$ & 1.000 & .777 & .797 & .757 & .506 \\
\hline & Structure & .777 & 1.000 & .712 & .441 & .185 \\
\hline & $\begin{array}{l}\text { Communicati } \\
\text { on }\end{array}$ & .797 & .712 & 1.000 & .540 & .364 \\
\hline & $\begin{array}{l}\text { Management } \\
\text { system }\end{array}$ & .757 & .441 & .540 & 1.000 & .336 \\
\hline & Culture & .506 & .185 & .364 & .336 & 1.000 \\
\hline \multirow[t]{5}{*}{$\begin{array}{l}\text { Sig. (1- } \\
\text { tailed) }\end{array}$} & $\begin{array}{l}\text { Employee's } \\
\text { performance }\end{array}$ & . & .000 & .000 & .000 & .000 \\
\hline & Structure & .000 & . & .000 & .000 & .006 \\
\hline & $\begin{array}{l}\text { Communicat } \\
\text { ion }\end{array}$ & .000 & .000 & . & .000 & .000 \\
\hline & $\begin{array}{l}\text { Management } \\
\text { system }\end{array}$ & .000 & .000 & .000 & . & .000 \\
\hline & Culture & .000 & .006 & .000 & .000 & . \\
\hline $\mathrm{N}$ & & 181 & 181 & 181 & 181 & 181 \\
\hline
\end{tabular}

Source: Survey Result (2018)

Hence, a result from Table 4.6 all the independent variables (organizationalculture, management system, structure and communication) have a significant positive correlation with dependent variables (employee's Performance).This means changes in one variable are strongly correlated with changes in the second variable. As all the correlations are positive it shows that when one variable increases/ decreases then the other would also increase or decrease. The significance level when seen at $95 \%$ level of significance the $\mathrm{p}$ value is less than 0.05 so the null hypothesis is rejected.

\subsection{Chi-square Test between Organizational Factors and Employees Performance}

Chi-square test is a statistical method for assessing the goodness of fit between a set of observed values and those expected theoretically. These results were presented in Table 4.7. The Chi-square statistics determines whether the observed values from the sample and expected values from the specified distribution are statistically different compared to the p-value (sig. value) to the significance level. Usually, a significance level (denoted as $\alpha$ or alpha) of 0.05 works well. A significance level of 0.05 indicates a $5 \%$ risk of incorrectly rejecting the null hypothesis.

Thus, P-value (sig.) $\leq \alpha$ : The observed data are statistically different from the expected values $\left(\right.$ Reject $\left.\mathrm{H}_{0}\right)$. In other word, If the p-value is less than or equal to the significance level, reject the null hypothesis and conclude 
that there was a significant association between the Organizational Factors and the Employee's Performance in the Public Service Organizations. Moreover, the basis of four Organizational Factorshave significant association with the Employee's Performance. This implies that, there was a strong association betweenOrganizational Factors and Employee's Performance of Public Service Organizations.

Table: 4.7. Chi-square Test between Organizational Factors and Employees Performance

\begin{tabular}{lllll}
\hline Factors & Structure & Communication & Management & Culture \\
\hline Chi-square & $641.832^{\mathrm{a}}$ & $683.463^{\mathrm{a}}$ & $831.035^{\mathrm{a}}$ & $685.363^{\mathrm{a}}$ \\
Df & 323 & 289 & 340 & 374 \\
Sig. & .000 & .000 & .000 & .000 \\
\hline
\end{tabular}

Source: Survey Result (2018)

\subsection{Stepwise Multiple Linear Regression}

The data collected through questionnaires was tested by SPSS. Initially we began with testing the assumptions of regression

1. The data should be a normally distributed

2. Homoscedasticity

The data was plotted and we found that in maximum cases the condition of normal distribution is fulfilled. The variance of the error is constant across observations. Therefore, we are applying multiple regressions to test the hypothesis and proposed model

The first table 4.8 tells us the model history SPSS has estimated. Since we have selected a stepwise multiple linear regression SPSS automatically estimates more than one regression model. If all of our four independent variables were relevant and useful to explain the employee's performance score, they would have been entered one by one and we would find four regression models. In this case however, we find that the best explaining variable. Organizational Communication, which is entered in the first step, Organizational Management System is entered in the second step, and Organizational Structure is entered in the third step while Organizational Culture is entered in the fourth step. After the fourth model is estimated, SPSS stops building new models because none of the remaining variables increases F sufficiently. That is to say, none of the variables adds significant explanatory power of the regression model.

Table: 4.8. Variables Entered/RemovedOrganizational Factors and Employees' Performance

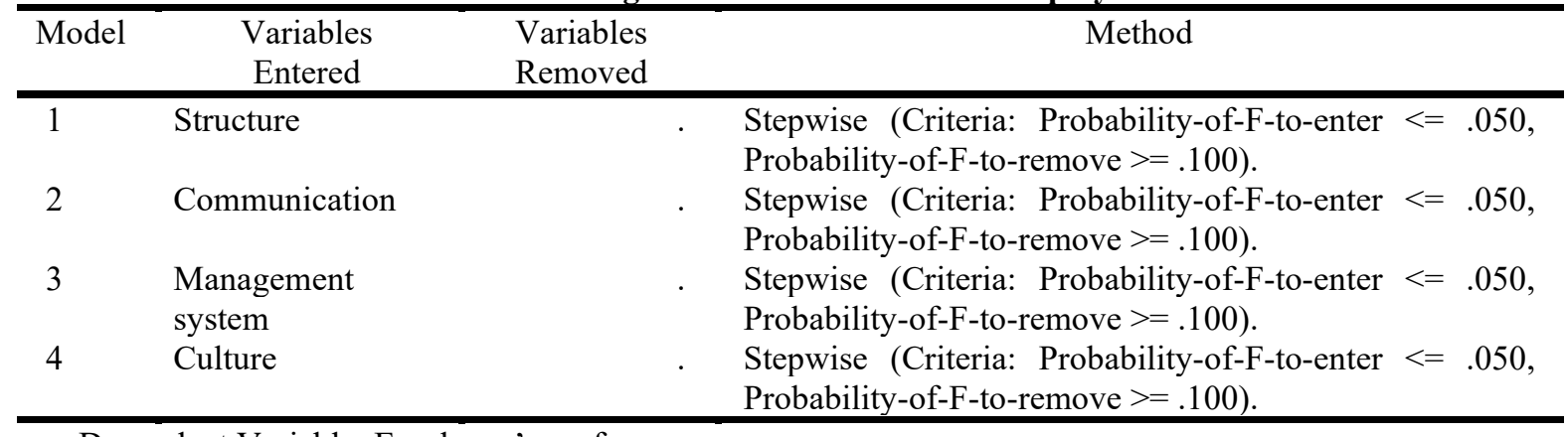

a. Dependent Variable: Employee's performance

Source: Survey Result (2018)

\subsection{Model Summary}

$\mathrm{R} 2$ means the proportion of the total variation in the $n$ observed values of the dependent variable that is explained bythe overall regression model (Bowermanet al., 2005). The higher $\mathrm{R}^{2}$, the better the model fits your data. $\mathrm{R}$ is the positive squared root of $\mathrm{R}^{2}$ (Levin \& Rubin, 1994). The next table shows the stepwise multiple linear regression model summary and overall fit statistics. We find that the adjusted $\mathrm{R}^{2}$ of our model 4 is 0.893 with the $\mathrm{R}^{2}=0.896$ the better the model fits to the data.This means that the linear regression model with the independent variables organizational Structure, organizational Communication, organizational Management system and organizational Culture explains $89.6 \%$ of the variance of the employee's performanceof public service organizations, while the remaining 10.4 percent are linked with other factors. 
Table: 4.9. StepwiseModel Summaryof Organizational Factors and Employees' Performance

\begin{tabular}{|c|c|c|c|c|c|c|c|c|c|}
\hline \multirow[t]{2}{*}{ Model } & \multirow[t]{2}{*}{$\mathrm{R}$} & \multirow[t]{2}{*}{$\mathrm{R}^{2}$} & \multirow{2}{*}{$\begin{array}{l}\text { Adjusted } \\
\mathrm{R}^{2}\end{array}$} & \multirow{2}{*}{$\begin{array}{l}\text { Std. } \\
\text { Error of } \\
\text { the } \\
\text { Estimate }\end{array}$} & \multicolumn{5}{|c|}{ Change Statistics } \\
\hline & & & & & $\mathrm{R}^{2}$ & $\begin{array}{l}\text { F } \\
\text { Change }\end{array}$ & df1 & $\mathrm{df} 2$ & $\begin{array}{l}\text { Sig. F } \\
\text { Change }\end{array}$ \\
\hline 1 & $.797^{\mathrm{a}}$ & .634 & .632 & .319 & .634 & 310.682 & 1 & 179 & .000 \\
\hline 2 & $.886^{\mathrm{b}}$ & .785 & .783 & .245 & .151 & 125.033 & 1 & 178 & .000 \\
\hline 3 & $.924^{\mathrm{c}}$ & .855 & .852 & .202 & .069 & 84.299 & 1 & 177 & .000 \\
\hline 4 & $.946^{\mathrm{d}}$ & .896 & .893 & .172 & .041 & 69.094 & 1 & 176 & .000 \\
\hline
\end{tabular}

a. Predictors: (Constant), Communication

b. Predictors: (Constant), Communication, Management system

c. Predictors: (Constant), Communication, Management system, Structure

d. Predictors: (Constant), Communication, Management system, Structure, Culture

e. Dependent Variable: Employee's performance

Source: Survey Result (2018)

The value of the Durbin-Watson test ranges from 0 to 4 , where values close to 0 indicate a strong positive autocorrelation while those close to 4 indicate a strong negative autocorrelation. Durbin-Watson tests that are close to 1 indicate no first-order autocorrelation. In this study, the Durbin-Watson statistic was 1.025, which was close to 1 implied that there was no first order autocorrelation in the residuals. The findings in table 4.6, confirmed that there was no autocorrelation in the data.

\subsection{Method: Enter}

If we would have forced all independent variables (Method: Enter) into the linear regression model summary we would have seen $\mathrm{R}^{2}=89.6 \%$ and adjusted $\mathrm{R}^{2}=89.3 \%$ an identical with stepwise multiple linear regression model. Table: 4.10. Enter Model Summaryof Organizational Factors and Employees' Performance

\begin{tabular}{|c|c|c|c|c|c|c|c|c|c|}
\hline \multirow{2}{*}{$\begin{array}{l}\text { Mode } \\
1\end{array}$} & \multirow[t]{2}{*}{$\mathrm{R}$} & \multirow{2}{*}{$\begin{array}{l}\text { RSquar } \\
\text { e }\end{array}$} & \multirow{2}{*}{$\begin{array}{l}\text { Adjuste } \\
\text { d } \\
\text { RSquare }\end{array}$} & \multirow{2}{*}{$\begin{array}{l}\text { Std. } \\
\text { Err } \\
\text { o }\end{array}$} & \multicolumn{5}{|c|}{ Change Statistics } \\
\hline & & & & & $\begin{array}{c}\text { RSquareChang } \\
\text { e }\end{array}$ & $\begin{array}{c}\mathrm{F} \\
\text { Chang } \\
\mathrm{e}\end{array}$ & $\begin{array}{c}\mathrm{df} \\
1\end{array}$ & $\begin{array}{l}\mathrm{df} \\
2\end{array}$ & $\begin{array}{l}\text { Sig. F } \\
\text { Chang } \\
\text { e }\end{array}$ \\
\hline 1 & $\begin{array}{l}.946 \\
\mathrm{a}\end{array}$ & .896 & .893 & .172 & .896 & 377.276 & 4 & 176 & .000 \\
\hline
\end{tabular}

a. Predictors: (Constant), Communication, Management system, Structure, Culture

b. Dependent Variable: Employee's performance

Source: Survey Result (2018)

\subsection{The F-test or ANOVA}

The next table is the F-Test is the test of significance of the stepwise multiple linear regressions. The four ANOVAs that are reported correspond to four models, but do not let the terminology confuse you. The stepwise procedure adds only one variable at a time to the model as the model is "slowly" built. At the third step and beyond, it is also possible to remove a variable from the model (although that did not happen in our study). In the SPSS, each step results in a model, and each successive step modifies the older model and replaces it with a newer one. Each model is tested for statistical significance. 
Table: 4.11. The F-Test or ANOVA

\begin{tabular}{|c|c|c|c|c|c|c|}
\hline \multicolumn{2}{|c|}{ Model } & Sum of Squares & df & Mean Square & $\mathbf{F}$ & Sig. \\
\hline \multirow[t]{3}{*}{1} & Regression & 31.629 & 1 & 31.629 & 310.682 & $.000^{\mathrm{b}}$ \\
\hline & Residual & 18.223 & 179 & .102 & & \\
\hline & Total & 49.853 & 180 & & & \\
\hline \multirow[t]{3}{*}{2} & Regression & 39.149 & 2 & 19.574 & 325.497 & $.000^{\mathrm{c}}$ \\
\hline & Residual & 10.704 & 178 & .060 & & \\
\hline & Total & 49.853 & 180 & & & \\
\hline \multirow[t]{3}{*}{3} & Regression & 42.602 & 3 & 14.201 & 346.646 & $.000^{\mathrm{d}}$ \\
\hline & Residual & 7.251 & 177 & .041 & & \\
\hline & Total & 49.853 & 180 & & & \\
\hline \multirow[t]{3}{*}{4} & Regression & 44.646 & 4 & 11.162 & 377.276 & $.000^{\mathrm{e}}$ \\
\hline & Residual & 5.207 & 176 & .030 & & \\
\hline & Total & 49.853 & 180 & & & \\
\hline
\end{tabular}

a. Dependent Variable: Employee's performance

b. Predictors: (Constant), Communication

c. Predictors: (Constant), Communication, Management system

d. Predictors: (Constant), Communication, Management system, Structure

e. Predictors: (Constant), Communication, Management system, Structure, Culture

Source: Survey Result (2018)

The F-test has the null hypothesis that there is no linear relationship between the variables (in other words $\mathrm{R}^{2}=0$ ). The F-test of all Models are highly significant, thus we can assume that there is a linear relationship between the variables in our model. The significance of the R Square can be tested by the $\mathrm{F}$ value and it has been found that there is a strong significant relationship (.000) between dependent variable with independent variables at $95 \%$ level of significance.From the ANOVA results shown in Table 4.11, we can see that the significance level is 0.000 $(p=0.000)$, which is below the 0.05 and therefore, there is a statistically significant.

The output shown in table 4.11 informs us that the final model was built in four steps; each step resulted in a statistically significant model. Examining the dfcolumn shows us that one variable was added during each step (the degrees of freedom for the Regression effect track this for us as they are counts of thenumber of predictors in the model). We can also deduce that no variables were removed from the model since the count of predictors in the model steadily increases from 1 to 4 .

\subsection{Assumptions for Regression Analysis for Organizational Factors and Employees' Performance}

Multiple linear regression analysis is quite sensitive, and as such it is vital to evaluate if there exist any outliers. It is because of this, that fundamental assumptions must be made, and examined before proceeding with regression analysis of variables.

\subsubsection{Testing for Linearity for Organizational Factors and Employees' Performance}

To establish that the relationship between independent variables of organizational factors and dependent variable of employees' performance was linear, linearity test was done and the results indicated in table 4.12.

Table 4.12 Linearity Test Results for Organizational Factors and Employees' Performance

\begin{tabular}{lcc} 
ORGANIZATIONAL FACTORS & \multicolumn{2}{c}{ COLLINEARITY STATISTICS } \\
& Tolerance & VIF \\
\hline Organizational Structure & .479 & 2.086 \\
Organizational Communication & .400 & 2.500 \\
Organizational Management system & .676 & 1.478 \\
Organizational Culture & .825 & 1.212
\end{tabular}

Organizational Culture

a. Dependent Variable: Employee performance

Source: Survey Result (2018)

The results showed that all the variance inflation factors (VIF) were below 10 . This clearly indicated that the relationship between the independent variables of (organizational factors) and dependent variable of (employees' performance) was linear.

\subsubsection{Regression Coefficients}

The next table shows the multiple linear regression coefficient estimates including the intercept and the significance levels. In our second model we find a non-significant intercept (which commonly happens and is nothing to worry about) but also highly significant coefficients for Organizational factors 1, 2, 3 and 4 models. 
Table: 4.13. Stepwise regression coefficients

\begin{tabular}{|c|c|c|c|c|c|c|}
\hline \multicolumn{2}{|c|}{ Model } & \multicolumn{2}{|c|}{$\begin{array}{l}\text { Unstandardized } \\
\text { Coefficients }\end{array}$} & \multirow{2}{*}{$\begin{array}{l}\text { Standardized } \\
\text { Coefficients } \\
\text { Beta }\end{array}$} & \multirow[t]{2}{*}{$\mathbf{t}$} & \multirow[t]{2}{*}{ Sig. } \\
\hline & & B & Std. Error & & & \\
\hline \multirow[t]{2}{*}{1} & (Constant) & 2.002 & .095 & & 21.086 & .000 \\
\hline & OrganizationalCommunication & .461 & .026 & .797 & 17.626 & .000 \\
\hline \multirow[t]{3}{*}{2} & (Constant) & 1.767 & .076 & & 23.266 & .000 \\
\hline & Organizational Communication & .317 & .024 & .547 & 13.268 & .000 \\
\hline & Organizational Management system & .199 & .018 & .461 & 11.182 & .000 \\
\hline \multirow[t]{4}{*}{3} & (Constant) & 1.426 & .073 & & 19.571 & .000 \\
\hline & Organizational Communication & .171 & .025 & .295 & 6.743 & .000 \\
\hline & Organizational Management system & .186 & .015 & .432 & 12.616 & .000 \\
\hline & Organizational Structure & .226 & .025 & .377 & 9.181 & .000 \\
\hline \multirow[t]{5}{*}{4} & (Constant) & .977 & .082 & & 11.890 & .000 \\
\hline & Organizational Communication & .123 & .022 & .212 & 5.501 & .000 \\
\hline & Organizational Management system & .166 & .013 & .384 & 12.980 & .000 \\
\hline & Organizational Structure & .249 & .021 & .415 & 11.809 & .000 \\
\hline & Organizational Culture & .171 & .021 & .223 & 8.312 & .000 \\
\hline
\end{tabular}

a. Dependent Variable: Employees' Performance

4.13.3. Hypothesis Testing for Organizational Factors and Employees' Performance

Regression analysis is a statistical method that is applied to establish the existing relationship between or among variables of study. Hypothesis testing is the process of comparing a research hypothesis with the null hypothesis. The null hypothesis is only rejected if its probability falls below a predetermined significance level, in which case the hypothesis being tested is said to have that level of significance.

Table 4.14: Result of Tested Hypotheses

\begin{tabular}{clrr}
\hline Hypothesis & Association between variables & Significant & Conclusion \\
\hline H1 & Organizational Communication & YES & Accepted \\
H2 & Organizational Management system & YES & Accepted \\
H3 & Organizational Structure & YES & Accepted \\
H4 & Organizational Culture & YES & Accepted \\
\hline
\end{tabular}

Source: Survey Result, 2018

Our regression equation would be: Employees' performance $=0.977+0.212 *$ Organizational Communication $+0.384^{*}$ Organizational Management system $+0.415^{*}$ Organizational Structure + $0.223^{*}$ Organizational Culture. For every additional point achieved on Employees' performance, we can interpret that the Organizational Structure Score increases by 0.415 , while for every additional score on Employees' performance Score increases by0.415. Model 4 is better model fits to the data than Model 1, 2 and 3.For the stepwise regression coefficients (table 4.12), the study found all Organizational factors coefficients value, $p<.05$ which was less than critical p-value of 0.05 , hence the study rejected the null hypothesis. This means that there was a significant and positive relationship between all Organizational factors and employees' performance in Dire Dawa Administration a case of selected public service organizations.

\subsection{The Significance of the Model}

Lastly, as the Goldfeld-Quandt test is not supported in SPSS, we check is the homoscedasticity and normality of residuals with an eyeball test of the Q-Q-Plot of $z^{*}$ pred and $z^{*}$ presid. The plot indicates that in our stepwise multiple linear regressions analysis there is no tendency in the error terms.

4.14.1.Normality Test. Ghozali (2006) states that the normality can be seen on the data distribution when the curve does not pass through either the left or the right. As depicted in Figure 4.1, it shows that the data output is normally distributed. 


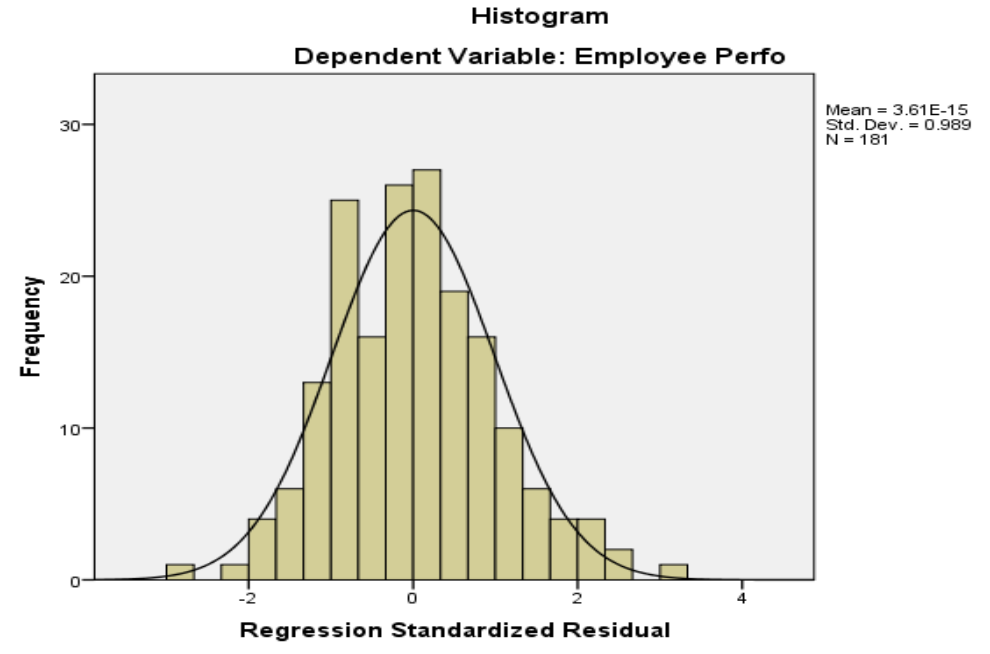

Figure 4.1 Histogram

4.14.2. Heteroskedastisity Test. This test can be done by looking at the scatterplot graphs presented in Figure 4.2 and 4.3 below. It shows that the dots spread randomly do not form any specific pattern which is clearly well dispersed above and below zero on the $\mathrm{Y}$ axis, and this means that the heteroscedasticity in the regression models is not incurred.

Scatterplot

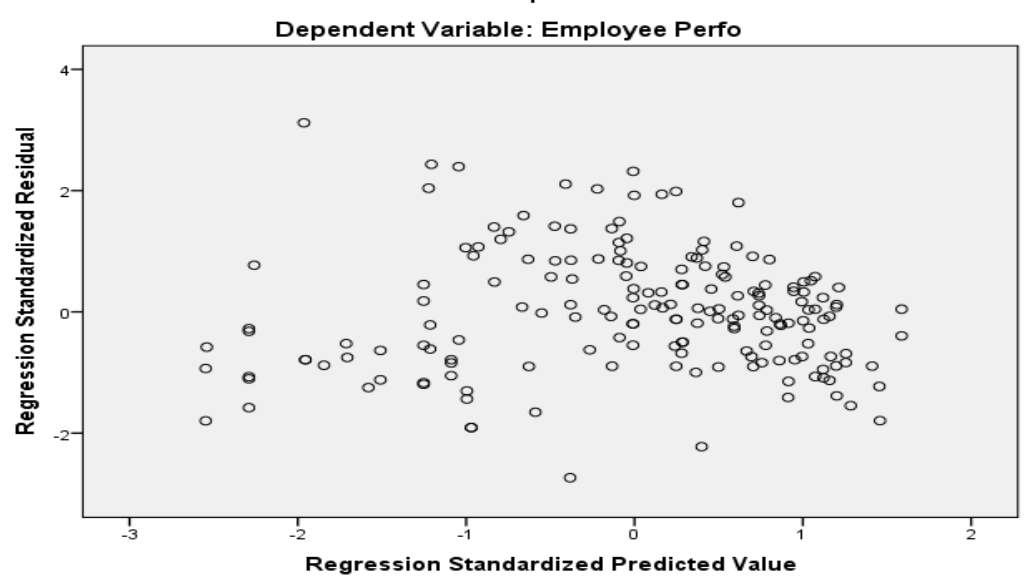

Figure 4.2: Scattered Plot Organizational Factors and Employees' Performance

\subsubsection{Linearity Test model}

Then, MLR should have linear relationship between response variable and controlled variables. in regression themodel, we fit is a linear model ('linear model' just means 'model based on a straight line').

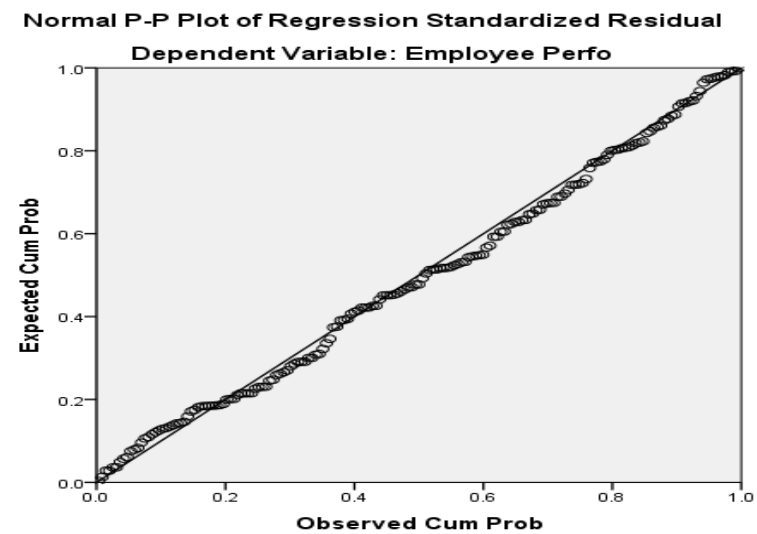

Figure 4.3:Normal P-P Plot of Regression Standardized Residual 


\section{Conclusions and Recommendations}

The study concludes that clear working standards leads to the implementation of performance management standards. Rules are designed to ensure a uniform and controlled standard of directing or managing worker's affairs, which helps in the implementation of performance management systems. Coordination of effort can establish and build a culture within which teams and individuals can take responsibility for developing their own skills, performance and behavior. Leaders play an important role in designing policies, which ensure an efficient management of performance in an organization and to define and act upon the core values relating to performance. An effective performance management process enables the top management to evaluate and measure individual and team performance and to optimize performance and productivity to meet the organizational goals. Employees are always polite to one another and find they are free to discuss with supervisors their task requirements in order to cope well with the organization's objectives. Purposely, the current organizational culture motivates employees; promotes good performance; improves on employee/supervisor relations; demonstrates fair and equal treatment; and improve on teamwork; efficiency and effectiveness. Smooth communication within the organization's makes employees identify with it and also feel a vital part of it, hence improving on the way conflicts are handled within the communication brought about by improper communication channels.

The study therefore, recommends that leaders should play an important role in designing policies to ensure that there is an efficient management of performance in the organization, define and act upon the core values of the organization. Since organizational culture enhances employee performance, there is need to improve on this culture in the following ways. There is need to build and improve teamwork. Putting a team in place to connect with each other, not just on a work level, but also on a friendship level, is beneficial towards teamwork that is more effective in the future. Team-building exercises are an easy way to get the team on the same level, familiar with one another, and better at communicating in a variety of environments. Planning out-of-office retreats and exercises for the team is also a great way to encourage better teamwork. There is need for leadership development at the PSO. The creation of a great organizational culture demands the presence of good leaders those who know how to delegate, communicate and listen. Without a great leader in place, the team can lose sight of the importance of organized and effective teamwork. There is need to improve communication. Management should establish open lines of communication for all members and not just the managers and leaders in the organizational structure. There is need to communicate frequently. Most employees appreciate transparent management because it keeps them informed of executive decisions that may affect their jobs. Consistent corporate communication helps minimize negative rumors that would otherwise damage employee loyalty.

\section{Recommendations for Further Research}

This study only focused on four organizational factors that affect performance at PSO and there are other factors that affect employee performance at PSO. Therefore, future research should focus on other than Organizational Structure, Organizational Communication, Organizational Management system and Organizational Culture these and other factors which affect employee performance like motivation of employees, working environment and organizational policies, among others. Secondly, since it was on PSO that was focused on, other researchers can do further research on other private sectors and find out what factors affect them as well.

\section{REFERENCES:}

Strengthening the role of Human Resource Managers in the public sector for the effective implementation of the charter for public Service in Africa ,(14 - 18 March 2011 Addis Ababa, Ethiopia)

Adhikari, (2010) Human Resource Development (HRD) for Performance Management:The Case of Nepalese Organisations. International Journal of Productivity and Performance Management, 59 (4), 306 - 324.

Agwu (2014),Performance Management. The Business School University of Colorado at Denver and Health Sciences Center.

Ahmad, N. et al. (2014). Impact of Organizational Commitment and Employee Performance on the Employee Satisfaction.International Journal of Learning, Teaching and Educational Research.Vol. 1, No. 1, pp. 84-92.

Amari, S. (2014). The Relation Between Academic Education and Employees' Performance in Tehran ParsianEvin and Azadi Hotels. Unpublished master's thesis. Luleå University of Technology, Department of Business, Administration, Technology and Social Sciences.

Armstrong, M., and Angela, B., (2004). Performance Management: Action and Impact.CIPD, London.

Awadh, M. A. \&Saad, M. A. (2013).Impact of Organizational Culture on Employee Performance.International review of Management and Business Research.Vol. 2 Issue.1, pp 168-175.

BersisaKacho, TerefeZeleke and GoitomGebremedhin (2016), Implementation of Human Resource Management Reform Program and Civil Service Professionalism in Ethiopia: The Case of Selected Cities, Ethiopian Civil Service University (ECSU) Website: www.ecsu.edu.et

Bowerman, B.L., O’Connell, R.T. and Koehler, A.B. (2005).Forecasting, time series and regression. 4th ed. United States of America: Brooks/Cole Thomson Learning Inc. 
Bryman, A and Cramer, D (1997) Quantitative Data Analysis for Social Scientists with SPSS for Windows, London: Routledge

Bryman, A. \& Bell, E. (2011), Business Research Methods, USA: Oxford University Press.

Cascio, (2006) Understanding Performance Appraisal. Thousand Oaks: Sage.

Churchill, S. \& Gilbert, A. (1999). A Paradigm for Developing Better Measures of Marketing Constructs. Journal of Marketing Research 16: 64-73.

Cooper \& Schindler (2009), Performance appraisal: Essential characteristics for strategic control. Measuring Business Excellence, 12 (3), 24-32.

Cooper, D. R. \& Schindler, P. S. (2006). Business Research Methods (9th edition). USA: McGrawHill.

Cooper, D., \& Schindler, P. (2014).Business Research Methods. New York: McGraw-Hill Irwin.

Cresswell, J. W. \& Plano Clark, V. L.(2011), Designing and conducting mixed method research (2nd ed.). Thousand Oaks, CA: Sage.

Creswell, J. W. (2009), Research Design: Qualitative, Quantitative and Mixed methods Approaches (3rded.). London: Sega publishers.

Daft, (2010) Performance Management in the Not-for-Profit Sector with Reference to the National Trust for Scotland. Total Quality Management, 18 (3), $303-311$.

DDA Public Service \& HR Development, (2017)

Edgar Sisa(2014), Implementation of the performance management system in the ministry of foreign affairs and international co-operation of the botswana public service

Femi, A. F. (2014). The Impact of Communication on Workers' Performance in Selected Organizations in Lagos State, Nigeria. IOSR Journal Of Humanities And Social Science (IOSR-JHSS) Volume 19, Issue 8, Ver. II (Aug. 2014), pp, 75-82. www.iosrjournals.org

Ferris et al (1998) Performance Appraisal Satisfaction and Employee Outcome: Mediating and Moderating roles of work motivation. International Journal of Human Resource Management, Vol. 17 (3).

Fidel, (2001), Discovering Statistics Using SPSS, Second Edition, Sage, London.

Fischer, (1997).Performance management, job satisfaction and organizational commitment.British Journal of Management, 7 (2), 169-79

Fisher, D. (2005). Action inquiry and performance appraisals: Tools for organizational learning and development. Journal of the Learning Organization, 12 (1), 26-41.

Foot, M. \& Hook, C. (2008).Introducing Human Resource Management (5th Edition). Pearson Education Limited: Prentice Hall.

FuJin, D., Robbins, S.P.\& Judge, T.A. (2010), Corporate performance management. Measuring Business Excellence 7 (3), 15-21.

Furnham, A. 2004.Performance Management Systems. European Business Journal, $2{ }^{\text {nd }}$ Quarter, 16 (2), 83 - 94.

Ghozali, I. (2006). AplikasiAnalisisMultivariatdengan SPSS.CetakanKeempat, Semarang: BadanPenerbitUniv-

Glassman, Champagne \&Zugelder, (2011) Public Sector Reform in Africa: Issues, Lessons and Future Directions. Journal of Sustainable Development in Africa, 12 (8), 145 - 157.

Gujarati, D.N., (2003), Basic econometric, 4th International ed. McGraw Hill. New York, USA.

Hair, R., Kincheloe, J. L, \& McLaren, P. (2007).Rethinking critical theory and qualitative research. In E. T. Trueba\& Y. Zou (Eds.) Ethnography and schools: Qualitative approaches to the study of education, (pp. 87 - 138). Lanham, MD: Rowman and Littlefield

Hakim, N. C. (1982), Secondary analysis and social research: A guide to data sources and methods with examples, London: Allen and Unwin.

Harrington, D. (2006). Performance Management: A New Approach For Driving Business Results. Malden, MA: Wiley-Blackwell.

Harrison, V. (2013).Performance Management (2nd ed.). Boston: McGraw-Hill.

Hellriegel and Slocum (2009) Performance Management in the Public Sector.International Journal of Public Sector Management, 22 (6), 478-498.

Hellriegiel, D., Jackson, S.E., Slocum, J., Staude, G., Amos, T., Klopper, H.B., Louw, L. \&Oosthuizen, T. (2001).Management.South African Edition. Cape Town: Oxford University Press.

Hrebiniak, W. (2005).Performance appraisal and feedback: A consideration of national culture and a review of contemporary research and future trends. Thousand Oaks, CA: Sage Publications.

Huff, (2011), Performance Management: Pariah or Messiah. Public Personnel Management, 31 (2), Summer, 161 - 178.

IskandarMuda, Ahmad Rafiki and MartuaRezekiHarahap,(2014) Factors Influencing Employees' Performance: A Study on the Islamic Banks in Indonesia International Journal of Business and Social Science Vol. 5 No. 2

Janet M. Ruane (2006), Essentials of Research Methods. A Guide to Social Science Research. USA, Blackwell Publishing.

JneChebet ,(2015)Determinants of employees' performance in the county governments of Kenya; a case of 


\section{Bungoma County}

Kiragu and Mutahaba (2006), Performance Measurement is Only One Way of Managing Performance. International Journal of Productivity and Performance Management, 54 (7), 502-516.

Kleinbaum, Stuart \&Tushman, 2008).Self-designed teams in improving public sector performance and quality of working life. Public Performance and Management Review, 27(2): 110-122.

Kothari, C.R (2004), Research Methodology Methods \& Techniques. New Age International (P) Limited, Publishers, New Delhi.

Krefting and Frost (1985), Improving Productivity in the Public Sector.In Hope, K.R, Sr., and Somolekae, G. (Eds.), Public Administration and Policy Analysis in Botswana.Kenwyn: Juta\& Co, Ltd.

Kyarimpa, D. (2009). Analyzing performance appraisal as goal-directed behavior.Research in Personnel and Human Resources Management 10 (2), 121-185.

Lawson (1995), Performance appraisal effectiveness: A matter of perspective. Advanced Management Journal, 57 (2) $18-23$.

Levinm R.I. and Rubin, D.S. (1994).Statistics for management. 6th ed. Englewood Cliffs, N.J.: Prentice Hall.

Lumbasi G. W., Ouma C. A., K"Aol G. O. (2015). The Effect of Achievement Oriented leadership Style on the Performance of COYA Senior Managers in Kenya

MacDonald, J.B., Smith, K. (2003). The effects of technology-mediated communication on industrial buyer behavior.Industrial Marketing Management, Vol. 33.

Magee, K. C. (2002). The Impact of Organizational Culture on the Implementation of Performance Management (Doctoral dissertation). Available from Dissertations and Theses database (UMI No.3047909).

Manville \&Greatbanks, (2013). High performance work systems and intermediate indicators of firm performance within the US small business sector. Journal of Management, 28(6), 765-785.

Markus, L., (2014). Performance Management- Problems and Potential;12 Key Steps to Ensure Top Performance from Your Staff. Leanne Markus Centranum Ltd.

Mbithe, M. N. (2012). Determinants of employee performance in the Public universities: A case of the University of Nairobi, Kenya. Unpublished master's thesis, University of Nairobi, Kenya.

McGrath, F. \& MacMillan, C. (2010).Management: Leading people and organization in the $21^{\text {st }}$ century. New Jersey, Prentice-Hall publishers.

Meseret, Y., (2007). Performance Appraisal in Commercial Banks: A Case Study on DashenBank S.C.

Mills, S., Megginson, W., Worley, Z. \&Doolen, H. (2013).Performance Management: Concepts, Skills, and Exercises. Armonk, NY: M. E. Sharpe.

Mohammad, J. U., Rumana, H. L., \&Saad, M. H. (2013). Impact of organizational culture on employee performance and productivity: A case study of telecommunication sector in Bangladesh. International Journal of Business and Management, 8 (2), 63-77.

Mohammed, U. D. et al., 2014. The Relationship between Leadership Styles and Employees' Performance in Organizations (A Study of Selected Business Organizations in Federal Capital Territory, Abuja Nigeria).European Journal of Business and Management, 6(22), pp. 1-11.

Monge, Cozzens and Contractor (1992) An Evaluation of the Botswana Directorate of Corruption and EconomicCrime.The International Journal of Public Sector Management,12(7),604-614.

Mugenda, O. M. \&Mugenda, A. (2003).Research Methods: Quantitative and Qualitative Approaches. Nairobi, Kenya, Acts

Mutahaba\& Ally, (2008) Differences in the Performance of Public Organisations in Ghana: Implications for Public-Sector Reform Policy. Development Policy Review, 24 (6), 693 - 705.

Nabukeera, M., Ali.B.,\& Raja. N. B. (2014). Performance evaluation of public service institution (CQS) framework.World Journal of Social Science, Vol. 2, No. 1; 2015 pp. 1-25.http://wjss.sciedupress.com

Naharuddin, N. M. \&Sadegi, M. (2013). Factors of Workplace Environment that affect Employees performance: A case study of Miyazu Malaysia. Journal of Independent Research and Studies, Vol 2, No. 2 (April 2013) 66-78.

Naqvi, S. M., Ishtiaq, M., Kanwal, N \& Ali, M. (2013). Impact of Job Autonomy on Organizational Commitment and Job Satisfaction: The Moderating Role of Organizational Culture in Fast Food Sector of Pakistan. International Journal of Business and Management, 8(17), 92-102.New York: Longman.

Nassazi, N., (2013). Effects of Training on Employee Performance: Evidence from Uganda, Dissertation, VaasanAmmattikorkeakoulu University of Applied Sciences.

Obonge o S. O. (2009). Implementation of Performance Contracting in Kenya.International Public Management Review.Electronic journal at http://www.ipmr.net Vol. 10 issue 2

Ogbonna, E. \& Harris, L. (2000). Leadership style, organizational culture and performance: Empirical evidence from UK companies. International Journal of Human Resources Management, 11(4), 766-788.445-465.

Ojo, O. 2009.Impact of Assessment of Corporate culture on Employee Job Performance.Journal of Business Intellegence, vol.2, no.2, pp.388-397 
Olowu, D. (2009). Strategic Performance Management in the Public Sector. A background paper commissioned by the Common-w ealth Secretariat for Meeting of African Heads of Public Service Mahe, Seychelles 12-16 July, 2009

Ooi, KB. Safa, MS. \&Arumugam, V. (2006), TQM practices and affective commitment: A case of Malaysian semiconductor packaging organizations. Entrepreneurship'.2(1):37-55.

Oyewobi, H., Wessels, J.S., Pauw, J.C. \& Van der Waldt, G. (2013) Comprehensive performance assessment in English local municipality. International Journal of Productivity and Performance Management 55 (6), 466479.

Pallant, J. (2005), SPSS Survival Manual, Second Edition, Allen \&Unwin, Sydney.

Proclamation No.416/2004 Provided Dire Dawa

Pulakos( 2004), Performance Appraisals in the public sector are they accurate and fair. Journal of Industrial Psychology. 27(1):54-60.

RamanadhKasturi (2006) performance management in insurance corporationJournal of Business Administration Online HTTP:// JBAO.ATU.EDU Vol. 5 No. 1

Robbin, H. \& De, Z. (2005).The mediating role of procedural justice in responses to promotion decisions.Journal of Business and Psychology 21 (1), 83-102.

Robbins, S. (2007). Towards efficiency and effectiveness in the public service.Journal of Public Administration 35 (1), 60-73.

Robbins. S. P. (2009), Organizational Behavior,13th edition. Pearson Education, New Delhi

Ruto, W. K. \&Datche, E. (2015) Logistical factors influencing port performance. A case of Kenya Ports Authority (KPA). International Journal of Current Research andReview, 7 (12), 52-59.

Saeed, R., Mussawar, S., Lodhi, R.N., Iqbal, A., Nayab, H.H. and Yaseen, S. (2013). Factors Affecting the Performance of Employees at Work Place in the Banking Sector of Pakistan, Middle-East Journal of Scientific Research 17(9): 1200-1208,

Sackman\&Bertelsman, (2006). Performance management analysis: a case study at Dutch municipality. International Journal of Productivity and Performance Management 55 (1), 26-39.

Sarantakos, S. (1988), Social Research, Second Edition, Palgrave, New York.

Saunders, M, Lewis, P and Thorn hill, A. (2016).Research Methods For Business Students, HE: UK .Pearson.

Saunders, M., Lewis, P. \&Thornhill, A. (2012).Research Methods for Business Students. Harlow: Pearson Education Limited.

Scholfelder (1998), The performance management source book. Amherst, MA. Human resource development press inc.

Scholz (1987), Implementing Performance Management and Recognition and Rewards (PMRR) Systems at the Strategic Level: A Line Management-Driven Effort. Human Resource Planning, 12 (3), 205 - 220.

Schultz, S., Megginson, W., Worley, Z. \&Doolen, H. (2013) A system perspective of performance management in public sector organisations.International Journal of Public Sector Management 13 (5), 417-446.

Shazad et al (2013) HR Practices and Leadership Styles as Predictors of Employee Attitude and Behaviour.European Journal of Social Sciences, Vol. 14 November 2010.

Smidts, Pruyn and Riel (2001) Effects of Introducing a Performance Management System on Employees' Subsequent Attitudes and Effort. Public Personnel Management, 28 (3), Fall, 423 - 452.

Smither, James W. and London, Manuel (2009).Performance Management Putting Research into Action. San Francisco: Jossey-Bass a Wiley Imprint

Sun, S. (2012). Rediscovering performance management: systems, learning and integration. Measuring Business Excellence 14 (1), 109-123.

Tameemi, A., Khaldoon, S. \& Mustafa A. (2014). The Impact of Organizational Culture and Leadership on Performance Improvement in Iraq.The Built \& Human Environment Review, Volume 7, 2014, pp. 1-15.

TilayeKassahun. 2007. Civil Service Reform in Ethiopia: Achievements, Problems and Possible Solutions. Proceedings of the First National Conference on the Achievements, Challenges and Prospects of the Civil Service Reform Program Implementation in Ethiopia, Addis Ababa, May 31 - June 1, 2007.

Worley, Z. \&Doolen, H. (2006). The professional practice: how process defines performance management. International Journal of Productivity and Performance Management 53 (3), 261-267.

Yamaguchi (2009) Performance management in service operational settings: a selective literature examination.Benchmarking: An International Journal. 17(2):214-231.

Yasin, M.M. and Gomes, C.F. (2010) Performance management in service operational settings: a selective literature examination. Benchmarking: An International Journal. 17(2):214-231.

Zahargler, A. S. \&Balasundaram, N. (2011). Factors affecting employees‘ performance in Ready-Made Garments (RMGs) sector in Chittagong, Bangladesh. Petroleum-Gas University of Ploiesti, BULETIN; Vol. LXIII, No. 1, 9-15; Economic Sciences Series.

ZerihunDuressa and TesfayeDebela, (2014), leadership effectiveness in Ethiopian public service organizations at 
federal and regional levels.Journal of Law, Policy and Globalization ISSN 2224-3240 (Paper) ISSN 22243259. Vol.26, www.iiste.org

\section{AUTHORS}

First Author-BINIYAM KEBEDE DESTA ${ }^{1}$

Lecturer of Management, College of Business (Department Head of MBA)

Addis Ababa Medical and Business College

Second Author -ELIAS ALEMAYEHU WAKENE ${ }^{2}$

Lecturer of Industrial Engineering in Dire Dawa University

(MSC in Industrial Engineering) 